\title{
Figurative Idioms and Culture
}

\author{
Fangfang Ding \\ Sichuan Agriculture University \\ Sichuan, China
}

\begin{abstract}
This paper seeks to outline the main typology of cultural aspects under conventional figurative language, idioms in particular and to describe the connection between figurative idioms and culture as it becomes manifest in idiomatic data from several languages.
\end{abstract}

Keywords-idioms; culture; figurative

\section{INTRODUCTION}

An idiom is a phrase, saying or a group of words that has a metaphorical meaning, which has become accepted in common usage. An idiom's symbolic sense is quite different from the literal meaning or definition of the words of which it is made. There are a large number of Idioms and they are used very commonly in all languages. There are estimated to be at least 25,000 idiomatic expressions in the English language. Idioms in fact, evolve the language; they are the building blocks of a language and civilization. They also have great intensity to make a language interesting and dynamic. Idioms bring a spectacular illustration to everyday speech. They provide interesting insights into the use of words, languages and the thought processes of their speakers. They have a sense of mystery and fun about them.

In earlier stages of idioms research, the interest in cultural phenomena was varied. Until quite recently, topics like idiom syntax, idiom semantics, idiom pragmatics, including sociolinguistic and psycholinguistic perspectives, text-related modifications of idiom structure and crosslinguistic research, have figured more prominently in many studies from (Western) Europe than cultural topics.

Numerous studies have highlighted the fact that idioms are not only units of a sign system, language, but also carriers of cultures, pointing out the necessity for modern phraseological research to turn to cultural phenomena. What exactly constitutes the connection between figurative idioms and culture, however, has never been examined systematically. This chapter uses a typology of the cultural phenomena which underlie idioms, along with the relevant phraseological types, to explore this connection. In doing so, one has to consider both the literal and the figurative readings of idioms, as well as the different levels of describing, since there are various ways in which the cultural aspects may become manifest.

\section{DEFINITION OF CULTURE}

Although there is general agreement on the fact that culture plays an important role for most phraseological issues, only a few studies have actually treated the relation between phraseology and culture in detail. While it is true that titles of phraseological studies rarely use the words culture or cultural (judging from relevant bibliographies), the studies themselves make ample use of these terms (and words such as culture-specific, culture-based, culturally marked, culturally significant, culturally tainted, culturally bound, cultural connotations etc.). Due to the vagueness of the term culture specifity, Sabban (2007: 590) proposes replacing it with the term culture boundness. It should be added that the term cultural foundation has been applied when describing cultural elements that underlie idioms (Dobrovol'skij \& Piirainen 2005: 216ff.).

Most studies concerned with culture or terms derived from it make no attempt to define these terms. To understand them better, let us take a look at neighbouring disciplines and their treatment of the term culture. Notions of culture seem to fluctuate between a wide and a narrower concept. Wierzbicka (1992, 1996) for example, favours a wide concept, pointing out that almost everything in language reveals a certain degree of cultural specifics. She states that the meanings of most words differ from language to language because they are cultural artifacts, reflecting aspects of the cultures in which they were created. According to Wierzbicka (1996: 15), the concept underlying a word like German Seele is not identical to the concepts underlying the English word soul or the Russian word duša, etc. because these concepts are unique and culture-specific configurations of semantic features. It is not incorrect to use the term culture for these cases; however, such a broad definition almost renders the term semantically empty. In such cases we deal with a kind of language specific which has to be separated from culture specific.

A wide concept of culture is also used in the field of cultural anthropology. Here, culture refers to the broad fields of human behavior and social interaction, cf. Tylor's (1871: 1) often-quoted definition of culture as "that complex whole which includes knowledge, belief, art, morals, law, custom, and any other capabilities and habits acquired by man as a member of society". This classic anthropological notion of culture has been criticized, modified and developed further over the last decades. Central to this conception of culture is the idea of cultural models, which are shared by members of a given community and which make up their entire cultural knowledge (Shore 1996). Within the broad field of cultural models studied by anthropologists, linguistic cultural models are of particular interest for phraseology, since collectively shared cultural norms, attitudes or values can manifest 
themselves in presuppositions underlying proverbs and other prefabricated stereotypes. A notion of culture close to that of anthropology has also been applied to the description of linguistic formulae in a wider sense, emphasizing "the shared way of life of a group of people" (Sabban 2004: 403).

Other principal characteristics of culture come to the fore in the field of semiotics, particularly in the so-called semiotics of culture. The notions of culture in this field include both a wide concept of culture and a narrower one (Portis-Winner 1994). Central to the attempts at defining culture from a semiotic viewpoint is the human predisposition to create signs and to give significance to all things that surround us; culture is viewed as a system of symbols or meaningful signs. Some ideas of this semiotic view of culture, mainly elaborated by the Moscow-Tartu school, have been adopted by Dobrovol'skij \& Piirainen (2005: 213ff.) to describe cultural phenomena underlying figurative language, above all cultural symbols in phraseology (see Section3). Crucial are the various parts of cultural knowledge that stand behind figurative units. Culture can be seen as the sum of all ideas about the world (including fictional, mythological etc. ideas) that are characteristic of a given community.

\section{TyPOlOGY OF CULTURAL ASPECTS UNDERLYING IDIOMS}

This section tackles two questions: how is culture actually revealed in figurative idioms, and how can we categorize the cultural knowledge structures that underlie idioms? For this purpose, the distinction between a synchronic and a diachronic (etymological) level of description can be left out of consideration. However, it is convenient to concentrate on those idioms where there is little doubt about the kinds of cultural knowledge involved. We can use the typology of principal cultural phenomena that occur in figurative idioms developed by Dobrovol'skij \& Piirainen (2005: 214ff.). Relying on idiomatic material from many different languages as the starting point for research, one can note the emergence of structures of cultural phenomena that are strikingly similar to those established by semioticians, often resulting in triads such as social, material, and mental culture. The category 'mental culture', however, seems unsuitable for describing linguistic phenomena because language as a whole is a mental phenomenon. It is therefore replaced by the three types (a) textual dependence, (b) pre-scientific conceptions of the world and (c) cultural symbols. Complementing these types of cultural phenomena are the two types (d) aspects of material culture and (e) aspects of culture-based social interaction.

\section{A. Textual Dependence}

An important type of cultural foundation of phraseology can be labelled textual dependence. This group consists of idioms whose image components can be traced back to an identifiable textual source. There can be direct references to particular texts, original quotations, which gradually developed into idioms or proverbs, or there can be allusions to an entire text, summarizing a certain situation or the gist of a text. Idioms of this type have been explored very well for several European languages. Large groups are made up of items related to the Bible (see Williams this volume) or to fables (e.g. the black sheep; sour grapes); other groups make reference to works of belles-lettres, fairy tales, narratives, movies or even titles of books, films, TV shows, etc. (e.g. to gild the lily; with seven-league boots; a happy-hunting ground). Some idioms of this type display lexical irregularities that are 'inherited' from the source text, cf. to cast pearls before swine, using the rather uncommon word swine instead of the more usual pig. It would go beyond the scope of this chapter to list textual sources significant in other cultural areas, as for example the Koran for Arabic (Baccouche 2007), the Beijing Opera for Chinese phraseology (Ying \& Erh-li 1996: 49ff.) or Chinese literature, tales and legends for the phraseologies of several East Asian languages.

\section{B. Pre-scientific Conceptions of the World}

Idioms that are based conceptually on pre-scientific conceptions of the world make up another culturally relevant group. However, they have never been explored as systematically as have the links between idioms and wellknown texts. Subgroups of this type include, among other things, idioms whose underlying fictive concepts belong to folk belief (enough to make the angels weep), superstitions (to thank one's lucky stars) or old folk medicine (rejected in the course of later scientific developments). 'Humoral pathology' - the doctrine of the four fluids of the body, or humors, that determine the four prototypical temperaments was of great influence on the idioms of European languages. It can be recognized in idioms such as the French se faire du mauvais sang, se faire de la bile (to be worried) or the German jmdm. läuft die Galle über (sb.'s bile overflows; sb. becomes very angry). The cultural specifics of these idioms become even more comprehensible when we turn our attention to languages of 'distant' cultural areas. Yu (2003) explains the concept gall bladder in the Chinese culture and idoms, a concept which is deeply anchored in the theory of internal organs in traditional Chinese medicine. According to this edifice of medical ideas, which dates back thousands of years, the gall bladder serves to make judgments and decisions and determines the degree of a person's courage. Chinese idioms reflect the pre-scientific concept.

\section{Cultural Symbols}

In conventional figurative units such as idioms and proverbs, cultural symbols manifest themselves chiefly in one single key constituent that contains the relevant cultural knowledge (as opposed to the idiom as a whole). The motivational link between the literal and figurative readings of these constituents is established by semiotic knowledge about the symbol in question, about its meaning in culturally relevant sign systems other than language (e.g. in mythology, religions, popular customs, fine arts). The symbol undergoes a semantic reinterpretation: it is a sign whose primary content is used as a sign for denoting content. For example, the primary meaning of 'white' in the idiom whiter than white has shifted metonymically to meanings such as "honest", 'true' or 'morally pure'. Wolf assumes symbolic functions such as 'danger' (cry wolf) or 'economic despair' 
(keep the wolf from the door), which are recurrent in figurative language and supported by other cultural codes. This goes back to the semiotisation of the wolf as a dangerous, greedy, man-devouring demon in various cultural codes, from the Bible to fairy tales and modern comics (see Dobrovol'skij \& Piirainen 1997: 215, 2005: 253ff. for details).

\section{Aspects of Material Culture}

The cultural foundation of a large number of idioms can be ascribed to aspects of material culture, which are embedded in everyday life of the present or the past. All kinds of artefacts can be part of literal readings of idioms. Several idioms, spread across many languages, use achievements of modern technological culture such as motorized transport or telecommunications as their source frames (to see the light at the end of the tunnel, to be on the same wavelength as sb.). Idiosyncratic aspects of material culture in European standard languages seem to be rare. Possibly, the concept sauna, an essential part of the traditional culture of Finland, is a source frame that is unique to Finnish figurative idioms (lisätä löylyä 'to increase sauna steam' i.e. to cause a conflict to become more intense). In contrast to that, the idioms of dialects, or language varieties close to dialects, reveals an abundance of idioethnic realia. Luxemburgish idiom, for instance, is imbued with cultural realia of winegrowing and winemaking as source concepts (a productive constituent is Hatt 'a basket which winegrowers carried on the back for picking grapes or transporting soil to the vineyards' (Filatkina 2005: 348, 2006: 119)). Certainly the further one moves away from the relatively unified European cultures, the more elements of culture-specific artifacts can be found in idioms. The image components underlying several Japanese idioms, for example, reveal the traditional Japanese dwelling house with its veranda, sliding paper screens or tatami-straw mats (cf. Piirainen 1999; Dobrovol'skij \& Piirainen 2005: 193ff.).

\section{E. Aspects of Culture-based Social Interaction}

Aspects of culture-based social interaction can be used as an umbrella term for a heterogeneous group of idioms whose underlying cultural knowledge chiefly goes back to knowledge about social experiences and behaviors within a given community. This means that some shared knowledge about culture-based phenomena in a society is involved in the processing of these idioms. Sub-categories include, among other things, semiotised gestures (to take off one's hat 'to show one's admiration for sb./sth.'), gender specifics ( $\mathrm{sb}$. wears the trousers (at home, in the family) 'it is the wife rather than her husband or partner who is the dominant person in a household') and bans and taboos (to be under the influence 'to be drunk'). The cultural foundation of the latter lies in the need of the speech community to avoid direct naming and instead employ strategies of glossing over. Thus, all idioms revealing cultural models belong to this group, above all proverbs, regarded as giving information about which values are upheld in a given culture and expressing generally applicable rules governing social behavior (White 1987). Finally, routine formulae are part of social interactions and therefore belong to this type of cultural foundation as well.

The goal here is not to assign each and every idiom unambiguously to a particular type but to structure the cultural knowledge that shapes these units and lies at the very heart of idioms as a whole. It is therefore not necessary to draw sharp lines between these types, which tend to overlap and interrelate. The idiom cry wolf (type (c)) also belongs to type (a), as it goes back to an Aesopian fable. The idiom the green-eyed monster meaning 'extreme jealousy' is a quotation from Shakespeare's tragedy Othello, the Moor of Venice and as such belongs to type (a). The connection between the color green (or yellow) and emotions such as anger and envy, however, goes back to the pre-scientific 'humoral pathology' (type (b)), which in Shakespeare's days was still alive and appears throughout his popular dramas. Cultural symbols such as gold, lily or the symbolic number seven can be found in idioms of intertextual origin such as to gild the lily; with seven-league boots.

\section{CONCLUSION}

Idioms are regarded as the central and most irregular category of idioms. What makes idioms stand out from other idioms is their high degree of idiomaticity, which manifests itself in semantic reinterpretations and/or semantic opacity (Baranov \& Dobrovol'skij 2005; Dobrovol'skij 2007). First, let us look at an example where elements of culture are located on the level of the source domain. The idiom when hell freezes over (something will never happen) is motivated on the basis of shared cultural knowledge about hell as a hot place that will never freeze over. The literal reading of the idiom refers to cultural concepts of mythology or folk belief, passed on throughout the centuries. Let us compare this to the idiom to be left on the shelf said of a woman who is past an age at which she might expect to get married. Cultural aspects of the source domain (e.g. shelf as an object of material culture) can be disregarded here. Rather, the cultural dimension becomes apparent at the level of the actual meaning. The gender specifics are a stable component of the semantic structure of this idiom; there is no male counterpart. The idiom conveys the idea of conforming to the standard that only a woman (but not a man) should have married by a certain age and thus reveals a cultural model in contemporary society.

\section{REFERENCES}

[1] Sabban, A. Culture-boundness and problems of cross-cultural phraseology. In Burger, H., D. Dobrovol'skij, P. Kühn \& N. R. Norrick (eds.) Phraseology. An International Handbook of Contemporary Research, Vol. 1, 590-605. Berlin: de Gruyter, 2007.

[2] Dobrovol'skij, D. O. \& E. Piirainen. Figurative Language: CrossCultural and Cross-Linguistic Perspectives. Amsterdam: Elsevier, 2005.

[3] Wierzbicka, A. Semantics, Culture, and Cognition. Universal Human Concepts in Culture-Specific Configurations. Oxford: Oxford University Press, 1992.

[4] Wierzbicka, A. Semantics: Primes and Universals. Oxford: Oxford University Press, 1996 
[5] Tylor, E. B. Primitive Culture. Researches into the Development of Mythology, Philosophy, Religion, Language, Art, and Custom (2 Vols.), Vol. 1, 4th edn. London: John Murray, 1871.

[6] Shore, B. Culture in Mind: Cognition, Culture, and the Problem of Meaning. New York, NY: Oxford University Press, 1996.

[7] Sabban, A. Wege zu einer Bestimmung der Kulturspezifik sprachlicher Formeln. In Palm-Meister, C. (ed.) EUROPHRAS 2000. Internationale Tagung zur Phraseologie vom 15.-18. Juni 2000 in Aske/Schweden, 401-416. Tübingen: Stauffenburg, 2004.

[8] Portis-Winner, I. Semiotics of Culture. "The Strange Intruder". Bochum: Brockmeyer, 1994.

[9] Baccouche, M. G. (2007). Arabic phraseology. In Burger, H., D. Dobrovol'skij, P. Kühn \& N. R. Norrick (eds.) Phraseology. An International Handbook of Contemporary Research, Vol. 2, 752-758. Berlin: de Gruyter, 2007.

[10] Ying, C. \& P. Erh-li. Guanyongyu. Idiome des modernen Chinesisch. Eine Lehr- und Lernhilfe. Heidelberg: Julius Groos, 1996.

[11] Yu, N. Metaphor, body, and culture: The Chinese understanding of gallbladder and courage. Metaphor and Symbol, 2003, 18: 13-31.

[12] Dobrovol'skij, D. O. \& E. Piirainen. Symbole in Sprache und Kultur. Bochum: Brockmeyer. (2nd. edn, 2002), 1997.

[13] Filatkina, N. Phraseologie des Lëtzebuergeschen. Empirische Untersuchungen $\mathrm{zu}$ struk-turellen, semantisch-pragmatischen und bildlichen Aspekten. Heidelberg: Winter, 2005.

[14] Filatkina, N. Theory revisited: Aspekte der Bildlichkeit im Lëtzebuergeschen. In Häcki Buhofer, A. \& H. Burger (eds.) Phraseology in Motion I. Methoden und Kritik. Akten der Internationalen Tagung zur Phraseologie (Basel, 2004), 115-128. Baltmannsweiler: Schneider Verlag, 2006.

[15] Piirainen, E. Dat sitt in de Pöste. Das niederdeutsche Hallenhaus als bildliche Domäne westmünsterländischer Idiome. Kognitive und kultursemiotische Aspekte der dialektalen Phraseologie. Jahrbuch des Vereins für niederdeutsche Sprachforschung, 1999, 122: 115-142.

[16] White, G. M. Proverbs and cultural models. An American psychology of problem solving. In Holland, D. \& N. Quinn (eds.) Cultural Models in Language and Thought, 151-172. Cambridge: Cambridge University Press, 1987.

[17] Baranov, A. N. \& D. O. Dobrovol'skij. Zum Idiombegriff. In Breiteneder, E. \& D. O. Dobrovol'skij (eds.) Dostoevskij in Focus, 35-48. Wien: Verlag der Österreichischen Akademie der Wissenschaften, 2005.

[18] Dobrovol'skij, D. O. Cognitive approaches to idiom analysis. In Burger, H., D. Dobrovol'skij, P. Kühn \& N. R. Norrick (eds.) Phraseology. An International Handbook of Contemporary Research, Vol. 2, 789-818. Berlin: de Gruyter, 2007. 